\title{
GOVERNMENT EXPENDITURE AND ECONOMIC GROWTH NEXUS IN NIGERIA: EVIDENCE FROM NONLINEAR ARDL AND CAUSALITY APPROACHES
}

\section{Anthony Enisan Akinlo, Olufunmilayo Olayemi Jemiluyi}

(1) Department of Economics, Obafemi Awolowo University, Ile-Ife

(2) Department of Economics, Obafemi Awolowo University, Ile-Ife

\begin{abstract}
Anthony Enisan Akinlo
Department of Economics, Obafemi Awolowo University, Ile-Ife, Nigeria aakinlo@oauife.edu.ng

Article info

Paper category: Original Scientific Paper Received: $29 \cdot 9 \cdot 2017$. Accepted: 8.6.2018. JEL classification: $\mathrm{O}_{4}, 0, \mathrm{O}_{55}, \mathrm{R}_{15}$
\end{abstract}

Keywords Government expenditure; Economic growth; NARDL cointegration; Nigeria 


\section{ABSTRACT}

The kernel of the debate on the relation between government spending and economic growth is whether the former causes the latter or the latter causes the former. In addition, there is the issue of possibility of nonlinearity in the relation between government expenditure and economic growth.

Purpose. The purpose of this paper is to examine the relations between government expenditure and economic growth in Nigeria.

Design/Methodology/Approach. The nonlinearity and causality in the relation between government expenditure and economic growth are examined using nonlinear autoregressive distributed lag model (NARDL), vector error correction model (VECM) and causality.

Findings/Implications. The findings show the existence of cointegration and nonlinear effect on the relation between government expenditure and economic growth in both long- and short-run. The results equally show unidirectional causality that runs from economic growth to government expenditure thus providing support for Wagner's law in $\mathrm{Ni}$ geria.

Originality. The findings from this study suggest that nonlinearity and asymmetry should be taken into account when examining the nexus between government expenditure and economic growth. 


\section{INTRODUCTION}

Over the last three decades, the empirical study of the government expenditure-economic growth relation has attracted a great deal of attention in the literature both in the developed and developing economies. The kernel of the debate has been whether the causality between the two variables runs from national income (measured as gross domestic product) to government expenditure or whether the causality runs from government expenditure to national income. The former perspective is associated with the Wagner's law, which is otherwise known as the law of increasing government expenditure. The latter view is associated with the Keynesian theory.

Wagner theory argues that the share of government expenditure tends to increase more than proportionally with economic activity because the goods and services provided by the public sector generally have income elasticities greater than one. Consequently, according to Wagner's law, the causality runs from national income to government expenditure, not in the opposite direction. According to the Keynesian view, an increase in government expenditure leads to an increase in economic growth through an expansionary fiscal policy. It is argued in the literature that as government spending increases, production also increases and thus aggregate demand, which ultimately leads to an increase in economic activity (GDP) ${ }^{1}$.

Without doubt, many studies have been conducted on the nexus between government expenditure and national income (measured as GDP); large numbers of the existing studies are focused on developed and industrialized economies. Not many studies have been conducted in Sub-Saharan African countries. Asides, many of the existing studies on the subject matter are fraught with one problem or the others. Firstly, many of the existing studies adopted bivariate analysis. Bivariate model has been found to produce biased results because of problem of omitted variables. As a matter of fact, introduction of other variables into a bivariate could affect not only the direction of causality but also the magnitude of the coefficients of the results. Secondly, some of the previous studies used cross-sectional data and thus not satisfactorily addressing the country-specific issues.

Thirdly and more importantly, all known studies have assumed linear relationship between government expenditure and national income when in actual fact, the relationship may be non linear. Indeed, the inconclusiveness and ambiguity of the various studies testing the government expenditure-economic growth nexus may have stemmed from the possibility of nonlinearity in the relationship. The possibility of nonlinear relationship between government expenditure and economic growth is very high. This is based on the fact that economic structure always undergoes structural and behavioral changes. Consequently, the dynamics of government expendi-

1 Empirical support for the Wagner's law can be found in the works of (Olomola, 2004; Aregbeyen, 2006; Lamartina and Zaghini, 2011; Mahdavi, 2009; Akinlo, 2013; Bayrak and Esen; 2014). However, the works of Huang, 2006; Dogan and Tang, 2006; Alimi, 2013; Ebaidalla, 2013; and Okoro, 2013 have provided evidence in support of the Keynesian hypothesis. 
ture in response to changes in economic growth could be diverse and vary in magnitude across phases of the economic cycle. As an illustration, the Wagner law suggests that the elasticity of government expenditure with respect to economic growth will be the same and greater than unity over the boom-bust cycle. Indeed, empirical evidence has shown that relative share of government expenditure in GDP rises in the boom and rather than declining in response to falling GDP in subsequent bust, it often remains high (Hercowitz and Stawczynski, 2004; Ageli, 2013). This argument follows from Ratchet hypothesis (Bird, 1972) that government expenditure ratchet up in the boom and declines little or not at all during the bust. Given this fact, there is the need to investigate government expenditure-growth nexus accounting for possible asymmetric fluctuations of expenditure over economic growth and vice-versa.

This study, therefore, is an attempt to correct the weaknesses of the existing studies by using nonlinear ARDL cointegration methodology (NARDL) proposed by Shin, Yu and Greenwood-Nimmo (2011) for Nigeria ${ }^{2}$. In order to take care of problem of omitted variable bias, the study incorporates two variables namely inflation and trade openness, thus creating a multivariate model. Essentially, a better understanding of the dynamic relation between government expenditure and GDP will aid the comprehension of policy-relevant issues over a short-to medium term horizon. Moreover, estimates from the analysis, in particular, the speed at which government expenditure adjust to the long-term relation with GDP after a shock in economic activity will assist in formulating budgetary adjustment plans that can help in achieving medium term budgetary objective or correct excess deficits in the economy.

Nigeria is an ideal country for examining the relationship between government expenditure and economic output since government in the country plays a significant role in the economy. The government is not just the largest employer of labour, it plays a vital role in the distribution and allocation of the available resources. In addition, a casual examination of the growth rate of government expenditure and output show that the two variables gyrate together over the years possibly reflecting the developments in the oil sector necessitating the need to know which one causes the other. Hence, the objectives of this paper are to examine the nonlinear relationship between government spending and national income measured as gross domestic product (GDP) and determine the direction of causality between the two variables.

The rest of the article is organized as follows: Section 2 discusses the trends in government expenditure and economic growth over the period 1960-2012. Section 3 describes the empirical approach and data. Section 4 presents the empirical results. Section 5 looks at the direction of causality between government expenditure and national income. The last section provides the conclusions.

2 Moreover, this methodology allows for asymmetry in both the long-and short run dynamics of the relationship examined. 


\section{TRENDS IN GOVERNMENT EXPENDITURE AND ECONOMIC GROWTH IN NIGERIA}

Government expenditure increased sharply in Nigeria between the period 1961 and 2016. It increased from N163.9 billion in 1961 to N903.9 billion in 1970. The figure increased from N1463.6 million in 1971 to N60.286 billion in 1990. Government expenditure increased phenomenally to N941.69 billion in 1999 but decreased to $\mathrm{N}_{7} \mathrm{O} 1.06$ billion in 2000. The figure increased consistently to $\mathrm{N}_{5160.74}$ billion in 2016. Generally in terms of the magnitude, government expenditure increased phenomenally between 1961-2016. This could be attributed to huge revenue from oil since early 70 s.

In the same government expenditure as a percentage of GDP was single digit and ranged between $6 \%$ and $9 \%$ over the period 1961 to 1967 . The percentage became double digit from 1968. Specifically, in 1968 the percentage was $13 \%$. The expenditure level increased consistently to $20 \%$ in 1972 though the level dropped from $17 \%$ in 1970 to $15 \%$ in 1971 . The total government expenditure, as a percentage of GDP decreased slightly to $18 \%$ and $15 \%$ in 1973 and 1974 respectively; it however, increased to $3 \circ \%$ in 1980 though there was slight drop to $18 \%$ in 1979. The large increase in government expenditure between 1968 and 1975 could be attributed partly to the civil war in Nigeria between 1969 and 1970 and partly to rehabilitation and reconstruction work that followed in the early 1970s. Government invested massively in infrastructure in the war torn areas.

Between 1981 and 2001, government expenditure as a percentage of GDP oscillated between $13 \%$ and $34 \%$. For example, the expenditure GDP was 34\% in 1993. This was the highest level recorded for the entire period 1960-2016. The expenditure level was consistently $10 \%$ and $14 \%$ between 2002 and 2009 . However, from 2010 to 2016 , the expenditure GDP ratio maintained a steady value of $5 \%$ to $7 \%$. Figure 1 . shows the trends of government expenditure and economic growth in Nigeria over the period 1961-2016. 
Figure 1.: Trends of government expenditure (ESP) and national income (GDP) in Nigeria

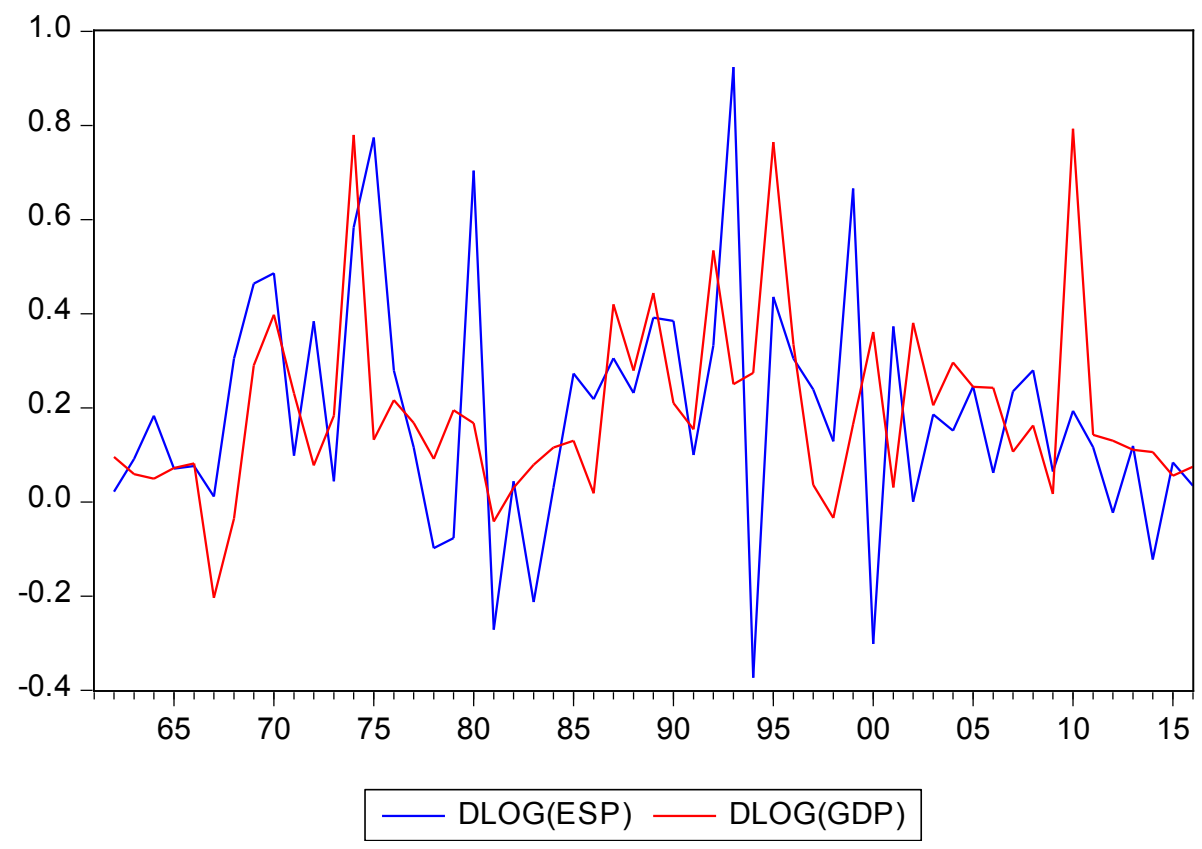

Source: Authors.

The national income (measured as GDP growth rate) increased marginally between 1961 and 1966 but became negative in 1967 and 1968 at $-0.184 \%$ and $-0.3 .5 \%$ respectively. This was a result of the civil war that started in 1967 . The rate was positive from 1969 to reach a peak of $11.8 \%$ in 1974. The increase GDP growth rate during this period could be attributed to increase oil production and revenue that started immediately after the civil war in 1970. The growth rate of the GDP maintained positive trend until 1981 when it turned at $-0.4 \%$. The trend reversed to positive from 1982 to 2016 except in 1998 and 2016 when the value was $-0.33 \%$ and $-0.24 \%$ respectively The negative rate of GDP growth in 1998 was a result of the political crisis that started with the annulment of the election in 1993 in the country, while that of 2016 was the result of the sharp drop in the price of oil and the aftermath of the general election of 2015. The average growth rate of GDP for the period 1961-1969 was $0.69 \%$. It however increased to 3\% for the period 1970-1979. The average GDP growth rate for periods 1980-1989 and 1990-1999 were $1.9 \%$ and 3.4\% respectively; while for the periods 2000-2009 and 2010-2016, they were $2.4 \%$ and $4.4 \%$ respectively. The corresponding average growth rates of government expenditure were $1.6 \%, 3.5 \%$ and $2.3 \%$ for periods $1961-1969,1970-1979$ and $1980-1989$ respectively. The average government expenditure growth rate increased from $2.3 \%$ for the period 1980-1989 to $4.4 \%$ in the period 1990-1999 but declined to $1.6 \%$ and $0.2 \%$ for the periods $2000-2009$ and $2010-2016$ respectively. 
In general, the main observation from Figure 1. is the close relationship between the trends of government expenditure and national income measured as GDP over the period 1961-2016. The close movement of the two variables makes rather difficult to know which one leads the other by mere causal observation. It is therefore imperative to conduct a more rigorous analysis of the nexus between government expenditure and national income in Nigeria while taking into account possible nonlinearity in their relationship in Nigeria.

\section{METHODS}

In the literature, the government expenditure-growth relations are usually examined by means of the standard time series techniques of cointegration, errorcorrection modeling and Granger causality. Although, these techniques are robust in assessing both the long run and short run relations, the implicit assumption in them is that the effects of changes in government expenditure on economic growth are symmetric. Accordingly, they are not adequate to capture potential asymmetries in the relations between government expenditure and economic growth. However recently, Shin et al (2011) developed a nonlinear ARDL cointegration methodology as an asymmetric extension to the well-known ARDL cointegration model of Pesaran and Shin (1999) and Pesaran, et al. (2001). The nonlinear ARDL is designed to capture both long run and short run asymmetries in a variable of interest.

To begin, we specify the following asymmetric long run equation of government expenditure in line with Peacock-Wiseman tradition ${ }^{3}$ :

$$
\text { ges }_{t}=\alpha+\beta^{+} g d p^{+}+\beta^{-} g d p_{t}^{-}+\mu \text { inf }_{t}+\chi \text { open }_{t}+e_{t}
$$

where ges is government expenditure, inf is the inflation rate and open is the degree of openness and gdp is the economic growth rate. $\alpha, \beta$ 's, $\mu$ and $\chi$ constitute vectors of long run parameters to be estimated. We have introduced two control variables in the equation (1) namely; inflation and trade openness based on the that other variables could have major impact on government expenditure. The omission of these variables could bias the direction of causality between government spending and national income ${ }^{4}$.

3 The Peacock-Wiseman version of the government-national income nexus specifies government expenditure as a function of national income. Other variants of this specification include Musgrave version, Goffman version and Gupta version.

4. The choice of inflation and trade openness as control variables is based on the argument in the literature that changes in trade exert a dominant influence on changes on nominal GDP and that one of the primary causes of fluctuations in national income. In the same vein, it is contended that inflation could drive up goverment spending leading to expansionary monetary policy, which affect interest rate and economic activity. 
In equation (1), $\beta^{+}$and $\beta^{-}$are partial sums of positive and negative changes in gdp: such that

$$
\begin{aligned}
& g d p_{t}^{+}=\sum_{j=1}^{t} \Delta g d p_{t}^{+}=\sum_{j=1}^{t} \max \left(\Delta g d p_{j}, 0\right) \\
& g d p_{t}^{-}=\sum_{j=1}^{t} \Delta g d p_{t}^{-}=\sum_{j=1}^{t} \min \left(\Delta g d p_{j}, 0\right) .
\end{aligned}
$$

Essentially, the long run relation as represented by equation (1) reflects asymmetric long run economic growth pass-through to government expenditure. As shown in Shin, et al. (2011), equation (1) can be framed in an ARDL setting along the line of Pesaran and Shin (1999) and Pesaran et al. (2001) as ${ }^{5}$ :

$$
\begin{aligned}
\Delta \text { ges }_{t}= & \text { g ges }_{t-1}+\delta_{1}^{+} g d p_{t-1}^{+}+\delta_{2}^{-} g d p_{t-1}^{-}+\delta_{3} \inf _{t-1}+\delta_{4} \text { open }_{t-1}+ \\
& +\sum_{j=1}^{p-1} \beta_{j} \Delta g e s_{t-j}+\sum_{j=0}^{q-1}\left(\eta_{j}^{+} \Delta g d p_{t-j}^{+}+\eta_{j}^{-} \Delta g d p_{t-j}^{-}\right)+\sum_{j=0}^{r-1} \theta_{j} \Delta \inf _{t-j}+\sum_{j=0}^{m-1} \varphi_{j} \Delta \text { open }_{t-j}+e_{t}
\end{aligned}
$$

where $\Delta$ denote the first difference and $\rho^{-1}, q^{-1}, r^{-1}$ and $m-1$ are the lag lengths.

Equation (2) is the usual model often used in past empirical studies to estimate the long run relationship between government expenditure and economic growth based on the assumption of linearity; except that this study has introduced the possibility of nonlinearity in modeling the relationship. Since all parameters contained in equation (2) are linear, the model can easily be estimated using standard ordinary least square (OLS) method.

The unrestricted specification of NARDL error correction model in equation (2) declares two different types of asymmetry; short and long-run asymmetries, which reflects two restrictions that can be tested by means of the standard Wald tests (Shin, et al., 2011):

(i) Long-run nonlinearity model where the null hypothesis of a linear longrun relationship can be tested through $\delta+=\delta$ -

(ii) Short-run nonlinearity model in which the null hypothesis of additive linearity can be tested through $\sum_{j=0}^{q-1} \eta_{j}^{+}=\sum_{j=0}^{q-1} \eta_{j}$

Based on the estimated NARDL, a test for the presence of cointegration among the variables using a bounds testing approach of Pesaran, et al. (2001) and Shin, et al. (2011) can be performed. This involves the Wald F test of the null hypothesis, $\rho=$ $\delta_{1}{ }^{+}=\delta_{2}{ }^{-}=\delta_{3}=\delta_{4}=0$. In the final step, given that variables are cointegrated, then examination of long and short run asymmetries in relations between national income and government expenditure is made and inferences are drawn. In this step,

For a more extensive derivation of the model see Shin, et al. (2011) 
we equally derive the asymmetric cumulative dynamic multiplier effects of a one per cent change in $\operatorname{gdp}_{\mathrm{t}-1}^{+}$and gdp ${ }_{\mathrm{t}-1}^{-}$respectively as:

$$
M_{h}^{+}=\sum_{i=0}^{h} \frac{\partial g e s_{t+i}}{\partial g d p_{t-1}^{+}}, \quad m_{h}^{-}=\sum_{i=0}^{h} \frac{\partial g e s_{t+i}}{\partial g d p_{t-1}^{-}} \quad h=0,1,2 \ldots
$$

$$
\text { Note that as } h \rightarrow \infty, m_{h}^{+} \rightarrow \beta^{+} \text {, and } m_{h}^{-} \rightarrow \beta^{-}
$$

To further assess the relationship between government expenditure and national income, we carry out granger causality test based on error correction model and obtained the the impulse response functions and the variance decompositions. The Granger causality based on error correction model helps not only to know the direction of causation but also to identify the variables that are exogenous and endogenous. Asides, the lagged ECM will inform us how it takes to revert back to equilibrium when there is shock to the variable. The VDC and IRFs will provide information on the relative degree of endogeneity and exogeneity of the variables.

\subsection{Data}

The time-series data adopted for the study are annual and cover the period1960-2016. The data series are sourced from World Bank, World Development Indicator (WDI) CD-Rom (2016) and Central Bank of Nigeria, Statistical Bulletin (2017) edition. Specifically, national income (measured as gross domestic product) (gdp), inflation (inf) measured as consumer price index $(1970=100)$ and openness (open) measured as sum of export and import as share of GDP were sourced from World Development Indicator. Government expenditure (GES) series was obtained from Central Bank of Nigeria; Statistical Bulletin. Gross domestic product and government spending are measured in million of domestic currency Naira.

\section{EMPIRICAL RESULTS}

\subsection{Empirical results and discussion}

Given the requirement of the bound testing procedure that no $I(2)$ variables are involved, we test for stationarity of the variables using ADF and PP unit roots. The results of these tests are given in Table 1 . In the tests, we include both constant and trend terms and employ the AIC and SIC for the optimal lag order. The results in table 1 show that three variables namely; government expenditure, gross domestic product and trade openness are non-stationary in levels but stationary at first differencing using the ADF test. However, inflation is stationary at level. The same results was obtained using Phillips-Perron test except for inflation variable which was stationary at level. 
Table 1.: Results of Unit Root Test

\begin{tabular}{|c|c|c|c|c|c|c|}
\hline \multirow[t]{2}{*}{ Variables } & \multicolumn{3}{|c|}{ Augmented Dickey-Fuller Test } & \multicolumn{3}{|c|}{ Philips-Perron Test } \\
\hline & Level & Difference ${ }^{\text {st }}$ & Remark & Level & $\begin{array}{r}1 s t \\
\text { Difference }\end{array}$ & Remark \\
\hline $\operatorname{lnGDP}$ & 0.456 & $-4.711^{* * * *}$ & $\mathrm{I}(1)$ & 0.644 & $-6.316^{* * * *}$ & $\mathrm{I}(1)$ \\
\hline $\operatorname{lnGES}$ & -1.246 & $-4 \cdot 74^{3 * * *}$ & $\mathrm{I}(1)$ & $-1.05^{8}$ & $-8.3 \circ 4^{* * * *}$ & $\mathrm{I}(1)$ \\
\hline $\operatorname{lnOpen}$ & -1.377 & $-4.081^{* * * *}$ & $\mathrm{I}(1)$ & -1.492 & $-8.99^{* * * *}$ & $\mathrm{I}(1)$ \\
\hline $\operatorname{lnInf}$ & $2.893^{*}$ & $-8.244^{* * *}$ & $\mathrm{I}(\mathrm{o})$ & $-4.112^{*}$ & $-12.730^{* * * *}$ & $\mathrm{I}(0)$ \\
\hline
\end{tabular}

Note: ****** and * denote significance level for $1 \%, 5 \%$ and $10 \%$ respectively.

Source: Authors.

In addition, we apply the Zivot-Andrews (1992) unit root test that allows for one endogenous structural break in the series. The results presented in Table 2, suggest that the variables examined except inflation turn to break stationary process in the first differences.

Table 2.: Unit Root with structural Break

\begin{tabular}{|l|r|r|r|r|r|}
\hline \multicolumn{1}{|c|}{ Variables } & level & Break Date & $\begin{array}{c}\text { First } \\
\text { Difference }\end{array}$ & Break Date & \multicolumn{1}{c|}{ Status } \\
\hline Ln GDP & -1.997 & 1986 & -7.013 & 1974 & $\mathrm{~L}(\mathrm{l})$ \\
$\ln$ GES & -2.2860 & 1985 & -9.390 & 1993 & $1(1)$ \\
$\ln$ Open & -2.180 & 1972 & -10.096 & 2009 & $1(1)$ \\
$\ln \operatorname{lnf}$ & $-5.202^{* * * *}$ & 1994 & - & - & $1(0)$ \\
\hline
\end{tabular}

Note: ${ }^{* * *}$ denote significance at $\mathbf{1} \%$.

The breaks coincide with major economic and political events in Nigeria. The year 1972 was when the country changed from Pound to Naira and introduced the metric system. In 1974, the Military reneged on the planned to handover power in 1976. In 1985, there was a military coup in the country. 1986 was when structural adjustment programme was implemented. 1993-1994 witnessed political upheavals arising from the cancellation of the general election by General Babangida. In 2009, there was constitutional crisis following the sickness of President Yar Adua and the disruption of oil production by Niger delta militants.

Source: Authors.

Given the fact that none of the variables is I(2), we then proceed to the bounds testing procedure.

Accordingly, we estimate equation (2) and apply the general-to-specific procedure to arrive at the model final specification. The maximum lag order considered is 3. Table 3. provides the results of the bounds F- statistics while Table 4. presents the model estimation results. The results of the bounds test shows that the four variables government expenditure, economic growth, openness and inflation rate, co-move in the long run. The statistic 9.94.1 exceeds the critical upper bound at both $5 \%$ and $1 \%$ level of significance. 
Table 3.: Bounds Test for Non-linear Cointegration

\begin{tabular}{|l|r|r|r|r|r|}
\hline \multicolumn{5}{|c|}{ Critical values } \\
\hline $\begin{array}{l}\text { F-Statistic } \\
\text { (prob) }\end{array}$ & $5 \%$ & & $1 \%$ & Remark \\
& Lower Bound & Upper Bound & Lower Bound & Upper Bound & \\
$9.941(0.001)$ & 2.86 & 4.01 & 3.74 & 5.06 & Cointegration \\
\hline
\end{tabular}

Source: Authors.

Table 4.: NARDL Estimation results

\begin{tabular}{|c|c|c|c|}
\hline \multicolumn{2}{|c|}{ Variable Coefficient } & T-Statistic & p-Value \\
\hline \multicolumn{4}{|c|}{ Dependent variable: $\Delta \ln G E S$} \\
\hline Constant & $5.35^{3^{* * * *}}$ & 6.912 & 0.000 \\
\hline $\operatorname{lnGes} \mathrm{t}_{\mathrm{t}-1}$ & $-0.865^{* * *}$ & $6.5^{19}$ & 0.000 \\
\hline $\operatorname{LnGdp}{ }_{t-1}$ & $0.697^{* * *}$ & 6.520 & 0.000 \\
\hline $\operatorname{lnGdp-t-1}$ & $-3.317^{* * * *}$ & $-4 \cdot 769$ & 0.000 \\
\hline $\operatorname{lnOpe_{t-1}}$ & $0.605^{* * * *}$ & 5.320 & 0.000 \\
\hline $\operatorname{Lnlnf}_{\mathrm{t}-1}$ & $0.081^{* *}$ & $2.13 \circ$ & 0.039 \\
\hline$\Delta \ln G d p+t$ & $0.319^{* * *}$ & 2.192 & 0.034 \\
\hline$\Delta \operatorname{lnGdp}{ }^{-}$ & 0.519 & $0.5^{19}$ & 0.607 \\
\hline$\Delta \operatorname{lnGdp}{ }_{t-1}$ & $1.769^{*}$ & 1.691 & 0.098 \\
\hline$\Delta \operatorname{lnOpen}{ }_{t}$ & $0.295^{* *}$ & 2.403 & 0.021 \\
\hline$\Delta \operatorname{lnInf} f_{t}$ & 0.041 & 1.208 & 0.234 \\
\hline \multicolumn{2}{|c|}{ Long-run (LR) asymmetric coefficients } & \multicolumn{2}{|c|}{ Long-and short-run symmetry tests } \\
\hline \multicolumn{2}{|c|}{$L R+\ln G d p=0.81^{* * * *}$} & \multicolumn{2}{|c|}{ WLR, $\ln G d p=23.09^{* * * *}(0.000)$} \\
\hline \multicolumn{2}{|c|}{$L R-\ln G d p=-3.83^{* * *}$} & \multicolumn{2}{|c|}{ WSR, $\operatorname{lnGdp}=14.75^{* * *}(0.000)$} \\
\hline \multicolumn{4}{|c|}{ Statistics and Diagnostics tests } \\
\hline \multicolumn{2}{|c|}{$\chi 2 \mathrm{SC}=0.47(0.63)$} & \multicolumn{2}{|c|}{$\chi_{2} \mathrm{HET}=0.24(0.99)$} \\
\hline \multicolumn{2}{|c|}{$\chi_{2} \mathrm{NORM}=37.01(0.000)$} & \multicolumn{2}{|c|}{$\chi_{2} \mathrm{FF}=0.20(0.65)$} \\
\hline
\end{tabular}

Note: ***** and * denote significance level for $1 \%, 5 \%$ and $10 \%$ respectively. WLR, WSR: Wald test for the null of long-and short-run symmetry respectively. $\chi^{2} \mathrm{SC}, \chi^{2} \mathrm{NORM}, \chi^{2} \mathrm{HET}$ and $\chi^{2} \mathrm{FF}$ refer to LM test for serial correlation, normality, functional form and heteroscedasticity, respectively.

Source: Authors.

The lower part of Table 4. presents some diagnostic tests of the estimated model. The tests for serial correlation LM $\left(\chi_{\mathrm{SC}}^{2}\right)$ and ARCH $\chi_{(\mathrm{HET})}^{2}$ test for heteroscedasticity indicate that the model estimated is well specified. In addition, graphs of the CUSUM and CUSUMSQ statistics to test for structural stability of the model as shown in Figures 2. and 3. respectively show parameter stability. In both cases, the statistics lie within the critical bounds implying that all the coefficients in the estimated model are stable.

The presence of asymmetric impact in the long and short run is examined by the Wald test. This checks the null hypothesis of symmetry against the alternative of 
asymmetry. The results as presented at the bottom of Table 4. show the significance of asymmetry in the long- and short-run for government expenditure and national income. This implies that taking nonlinearity and asymmetry into account is important when analyzing the relationship between government expenditure and national income.

Figure 2.: The Cumulative Sum Graph based on the Nonlinear Autoregressive Distributed Lag (NARDL) Model Estimation

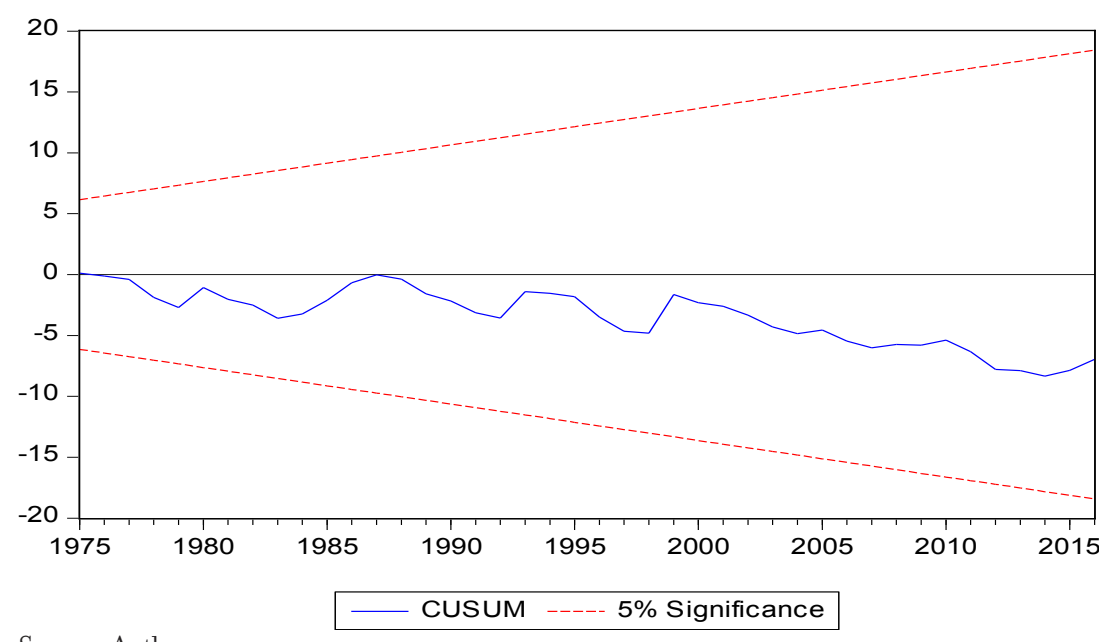

Source: Authors.

Figure 3.: The Cumulative Sum of Squares Graph based on the Nonlinear Autoregressive Distributed Lag Model (NARDL) Estimation

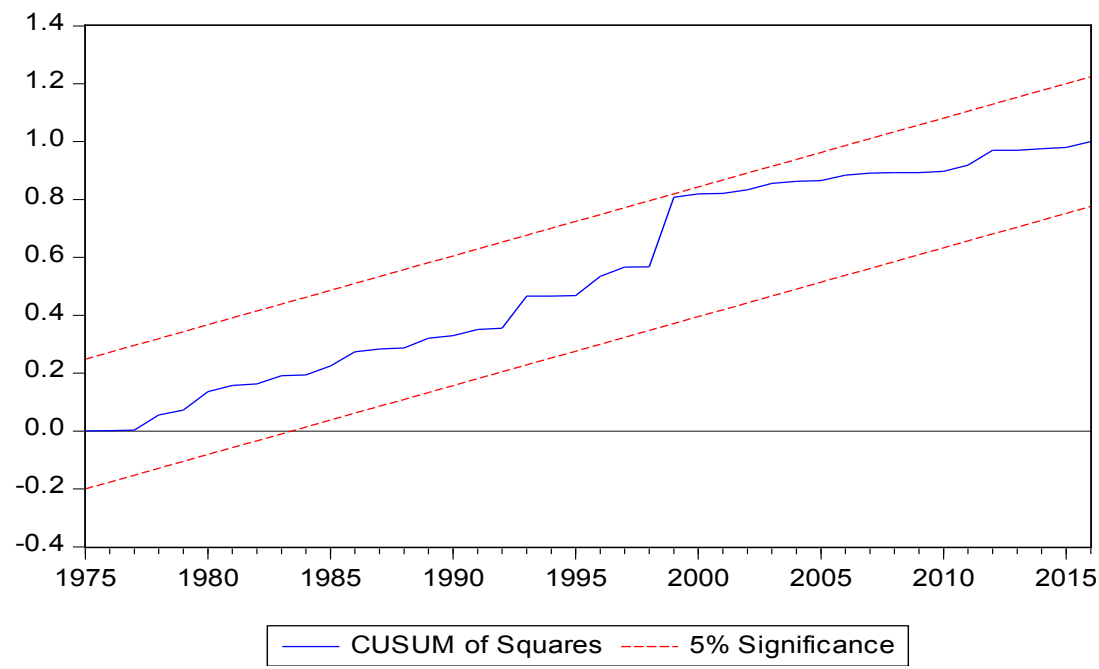

Source: Authors. 
The result as presented in Table 4. shows asymmetric long run relation between government expenditure and national income. The increase in national income (measured and GDP) is positive and significantly related to government expenditure while the reduction in national income is negative and significantly related to government expenditure. Specifically, the result shows that a $1 \%$ increase in gross domestic product is related to the increase in the expected government expenditure by $0.8 \%$. This finding implies that in the period of economic boom, government spends more. The result shows that economic growth is a major factor influencing government expenditure in Nigeria. This finding is in conformity with most empirical evidence in the literature (Bayrak and Esen, 2014; Akinlo, 2013; Olomola, 2004). In contrast, the effect of the negative component of GDP (economic downturn) on government expenditure is negatively significant and larger in magnitude, with a $1 \%$ decrease in government expenditure resulting in about 3.83\% decrease in government expenditure.

Simply put, in the long run, negative growth (economic downturn) has a considerably larger impact on government expenditure compared to positive growth (economic upturn). This finding suggests that government expenditure responses to variations in economic growth need not be the same during the booms (economic upturn) as during recessions (economic downturn) and should rather depend on the intensity/magnitude of the economic fluctuations. This is the main tenet of Bird (1971) Ratchet hypothesis, which posits an asymmetry in government expenditure share to GDP over the business cycle.

The long run coefficient of inflation is positive and significant at $1 \%$ significance level in line with a priori expectation. The results suggest that that $1 \%$ increase in domestic price level is related to the increase in expected government expenditure by roughly $0.1 \%$. In the same way, the coefficient of trade openness is positive and significant, in line with the literature (Rodrik, 1978). The results show that $1 \%$ increase in trade openness leads to $0.67 \%$ rise in government expenditure. This supports the findings of Aregbeyen (2014) and Adams and Sakyi (2012) for Nigeria and Sub-Saharan Africa respectively.

To investigate the pattern of dynamic asymmetric adjustment of government expenditure from its initial equilibrium to the new steady state in the long run shock, we use the dynamic multiplier propose by Shin et al (2014). Figure 4. shows the dynamic effects of positive and negative changes in national income where government expenditure responds more rapidly to a decrease in national income as compared to an increase. The positive (undotted line) and negative (dotted line) curves show the asymmetric adjustment to positive and negative shocks at a given forecast respectively. 
Figure 4.: Dynamic Multipliers effects

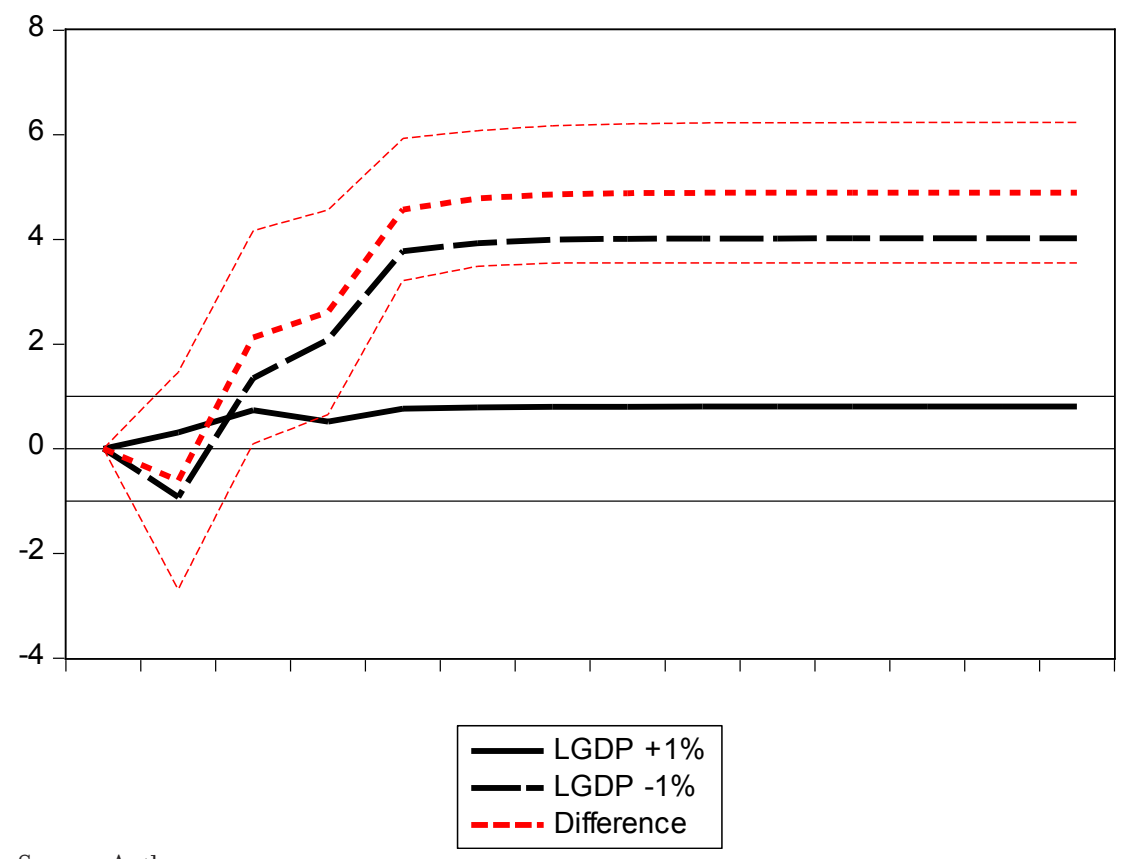

Source: Authors.

\section{GRANGER CAUSALITY RESULTS BASED ON VECM}

To assess the direction of causality, the paper conducts the Granger causality test based on error correction model. The error correction helps to confirm the long run relationship and assist to identify which variable is exogenous (strong) and which endogenous (weak) and the $\operatorname{ECM}(-1)$ is the speed of adjustment that informs us on how long it takes to revert back to long-term equilibrium if that variable of adjustment is perturbed. Table 5 presents the results of the error correction model while Table 6. shows the results of the causal channels. As evidenced from the t-statistic of the ECM, only inflation variable is significant and thus endogenous. Other variables are found to be exogenous (not statistically significant in the ECM results). This shows that a shock to inflation will have strong effect on government expenditure, national income and trade openness. This means that monetary policy must focus on inflation stability as it seems to have profound effect on government expenditure and on the growth of the economy. In terms of the direction of causation, the results in Table 6. shows the national income granger cause government expenditure and not otherwise. Also, the results show unidirectional causality from national income to openness and inflation. 
Table 5.: Error Correction Model

\begin{tabular}{|c|c|c|c|c|c|}
\hline & Coefficient & $\begin{array}{l}\text { Standard } \\
\text { Error }\end{array}$ & T-Statistic & Significant & Result \\
\hline$\Delta \mathrm{GES}$ & 0.0296 & 0.0594 & 0.4986 & $\begin{array}{r}\text { Not } \\
\text { significant }\end{array}$ & Exogenous \\
\hline$\Delta \mathrm{GDP}$ & -0.0098 & 0.0507 & -0.1875 & $\begin{array}{r}\text { Not } \\
\text { significant }\end{array}$ & Exogenous \\
\hline$\triangle \mathrm{OPEN}$ & 0.0668 & $0.05^{37}$ & $1.24,39$ & $\begin{array}{r}\text { Not } \\
\text { significant }\end{array}$ & Exogenous \\
\hline$\Delta \mathrm{INF}$ & $0.9248^{* * *}$ & $0.215^{3}$ & 4.2959 & Significant & Endogenous \\
\hline
\end{tabular}

Note: *** denote significance at $1 \%$

Source: Authors.

Table 6.: Granger-Causality Results based on VECM

\begin{tabular}{|c|c|c|c|c|}
\hline \multicolumn{5}{|c|}{ Independent Variables } \\
\hline \multirow{2}{*}{$\begin{array}{l}\text { Dependent } \\
\text { Variables }\end{array}$} & \multicolumn{4}{|c|}{$\chi^{2}$ of lagged first differenced term $[\rho$-value $]$} \\
\hline & $\Delta \mathrm{GES}$ & $\Delta \mathrm{GDP}$ & $\triangle O P E N$ & $\triangle \mathrm{INF}$ \\
\hline$\Delta \mathrm{GES}$ & --- & $\begin{array}{r}7.203^{* * * *} \\
(0.007)\end{array}$ & $\begin{array}{r}2.719 \\
(0.100)\end{array}$ & $\begin{array}{r}1.384 \\
(0.239)\end{array}$ \\
\hline$\Delta \mathrm{GDP}$ & $\begin{array}{c}0.007 \\
(0.935)\end{array}$ & --- & $\begin{array}{l}0.027 \\
0.870)\end{array}$ & $\begin{array}{r}0.752 \\
(0.386)\end{array}$ \\
\hline$\triangle \mathrm{OPEN}$ & $\begin{array}{r}0.045 \\
(0.833)\end{array}$ & $\begin{array}{l}4.223^{* * *} \\
(0.039)\end{array}$ & --- & $\begin{array}{r}1.987 \\
(0.159)\end{array}$ \\
\hline$\Delta \mathrm{INF}$ & $\begin{array}{r}0.801 \\
(0.371)\end{array}$ & $\begin{array}{c}3.011^{*} \\
(0.084)\end{array}$ & $\begin{array}{r}0.808 \\
(0.369)\end{array}$ & -.- \\
\hline
\end{tabular}

Note: ***, ** and * denote significance level for $1 \%, 5 \%$ and $10 \%$ respectively. The figure in parenthesis represents the p-value

Source: Authors.

While error correction model can show the absolute endogeneity or exogeneity of a variable; it cannot give us the relative degree of endogeneity and exogeneity of a variable. To achieve the latter; we generate the variance decompositions of the variables. The results from Generalized VDCs are as shown in Table 7 . The variable that is ranked higher is the leading variable, and therefore should be set as the immediate target by the policymakers. The results in Table 7 . for the 10 -years horizon, GDP is the most exogenous. All through the 10-years horizon, own shock accounts for over 90 per cent. Inflation is shown to be the most endogenous as own shock peters out rapidly to reach 57.11 per cent in the $10^{\text {th }}$ period. 
Table 7.: Variance Decompositions (VDCs)

\begin{tabular}{|c|c|c|c|c|}
\hline $\begin{array}{l}\text { LGES } \\
\text { Period }\end{array}$ & LGES & LGDP & LOPEN & LINF \\
\hline 1 & 100.0000 & 0.000000 & 0.000000 & 0.000000 \\
\hline 2 & 88.78236 & $8.7^{814} 12$ & 2.185496 & 0.250727 \\
\hline 3 & 87.66912 & $10.55^{327}$ & $1.57975^{6}$ & $0.197^{8} 5^{3}$ \\
\hline 4 & 87.29101 & $10.7487^{8}$ & 1.686946 & 0.273263 \\
\hline 5 & 87.20065 & $10.75^{229}$ & 1.666701 & o. $38 \circ 35^{8}$ \\
\hline 6 & 87.17504 & 10.62877 & 1.692683 & 0.503509 \\
\hline 7 & 87.17960 & $10.49^{8} 5^{8}$ & $1.7_{13} 3447$ & 0.608369 \\
\hline 8 & 87.18783 & 10.37939 & $1.7^{3} 27^{8} 4$ & 0.699990 \\
\hline 9 & 87.19920 & $10.275^{26}$ & 1.749547 & 0.775991 \\
\hline 10 & 87.20945 & 10.18717 & 1.763664 & 0.839718 \\
\hline $\begin{array}{l}\text { LGDP } \\
\text { Period }\end{array}$ & LGES & LGDP & LOPEN & LINF \\
\hline 1 & 6.817214 & $9^{3.18279}$ & 0.000000 & 0.000000 \\
\hline 2 & 6.560591 & 92.554 .05 & 0.039266 & $0.84,6094$ \\
\hline 3 & 6.611315 & 92.64394 & 0.079775 & 0.664968 \\
\hline 4 & 6.767703 & 92.54 .836 & 0.078700 & 0.605236 \\
\hline 5 & 6.870957 & $92.5 \circ 946$ & 0.079922 & $0.5^{39664}$ \\
\hline 6 & 6.965927 & 92.46096 & 0.078859 & 0.494254 \\
\hline 7 & 7.038196 & $92.425^{8} 7$ & $0.077^{828}$ & $0.45^{8102}$ \\
\hline 8 & $7.097^{387}$ & 92.39567 & 0.076835 & $0.4,30104$ \\
\hline 9 & 7.144948 & 92.3714 .6 & $0.07595^{2}$ & $0.4 .0764,0$ \\
\hline 10 & $7.184,048$ & 92.35132 & 0.075199 & 0.389429 \\
\hline $\begin{array}{l}\text { LOPEN } \\
\text { Period }\end{array}$ & LGES & LGDP & LOPEN & LINF \\
\hline 1 & 2.694232 & $0.635^{3} 94$ & 96.67037 & 0.000000 \\
\hline 2 & 4.933824 & $6.55^{8275}$ & 88.48872 & 0.019184 \\
\hline 3 & 6.479144 & $6.83_{7161}$ & $85.7065^{\circ}$ & $0.977^{192}$ \\
\hline 4 & 7.509922 & 6.632767 & 84.19326 & 1.664049 \\
\hline 5 & 8.244072 & $6.35_{2} 319$ & 82.98679 & 2.416824 \\
\hline 6 & $8.7^{81702}$ & $6.0555^{33}$ & 82.15457 & 3.008196 \\
\hline 7 & $9.184,229$ & 5.812929 & 81.50198 & 3.500862 \\
\hline 8 & 9.496007 & 5.609191 & $80.99^{8} 5^{8}$ & 3.896223 \\
\hline 9 & $9 \cdot 741_{1824}$ & $5 \cdot 442849$ & 80.59666 & 4.218664 \\
\hline 10 & $9.94024 \circ$ & 5.305284 & 80.27149 & $4 \cdot 482983$ \\
\hline $\begin{array}{l}\text { LINF } \\
\text { Period }\end{array}$ & LGES & LGDP & LOPEN & LINF \\
\hline 1 & 0.062498 & 0.372268 & 0.607918 & $98.957^{32}$ \\
\hline 2 & $1.307^{3} 56$ & 0.799702 & $4.114,096$ & $9^{3} .77^{88} 5$ \\
\hline 3 & 3.882307 & 2.891128 & 3.837434 & 89.38913 \\
\hline 4 & 6.937994 & 4.228931 & $3.8885 \circ 6$ & 84.94457 \\
\hline 5 & 10.29684 & $6.74,34,06$ & $3.6824,01$ & $79 \cdot 277^{3} 5$ \\
\hline 6 & 13.43608 & $9.04744^{2}$ & 3.476965 & $74.0395^{1}$ \\
\hline 7 & 16.31824 & 11.33861 & 3.265084 & 69.07807 \\
\hline 8 & 18.88354 & 13.41301 & 3.068051 & 64.63541 \\
\hline 9 & 21.16198 & 15.29133 & 2.888350 & 60.65834 \\
\hline 10 & 23.18268 & 16.9714 .8 & 2.726509 & 57.11933 \\
\hline
\end{tabular}

Source: Authors. 
We proceed further to find the impact of shock of one variable on others and validate the degree of response and how long it would take to normalize using the Impulse Response functions (IRFs). Figure 5., 6. and 7. are the graph for the period 10, 20 and 30 years. As revealed in Figures 5., 6. and 7., a perturbation to the inflation variables generate a fast response from the three other exogenous variables.

Figure 5.: Impulse Response Functions (IRFs) results - 10 years
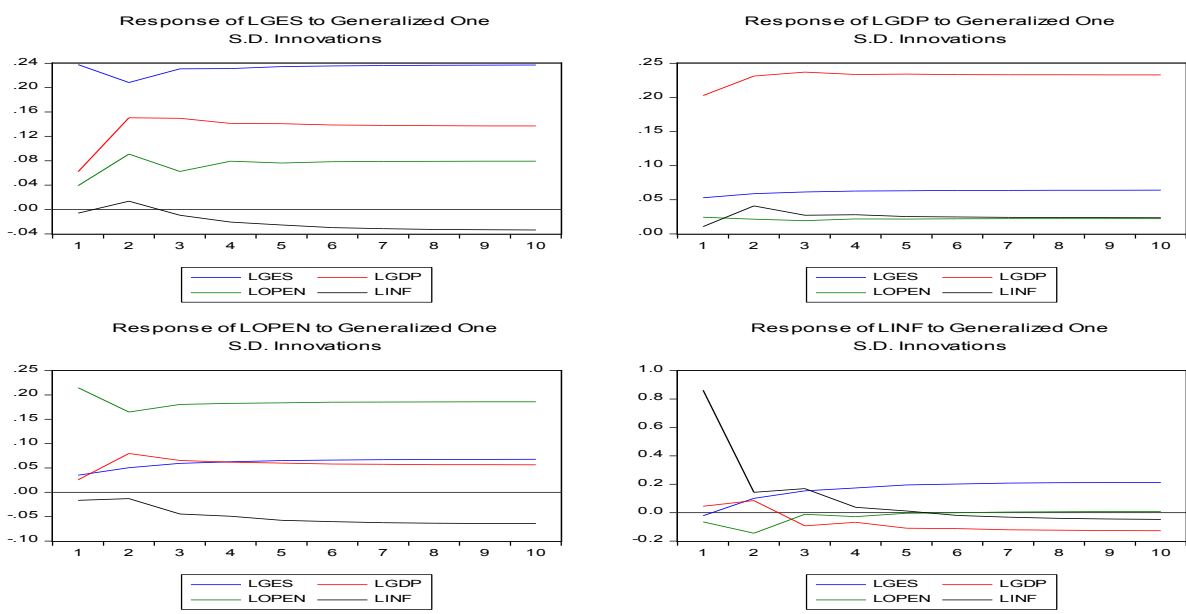

Source: Authors.

Figure 6. : Impulse Response Functions (IRFs) results - 20 years
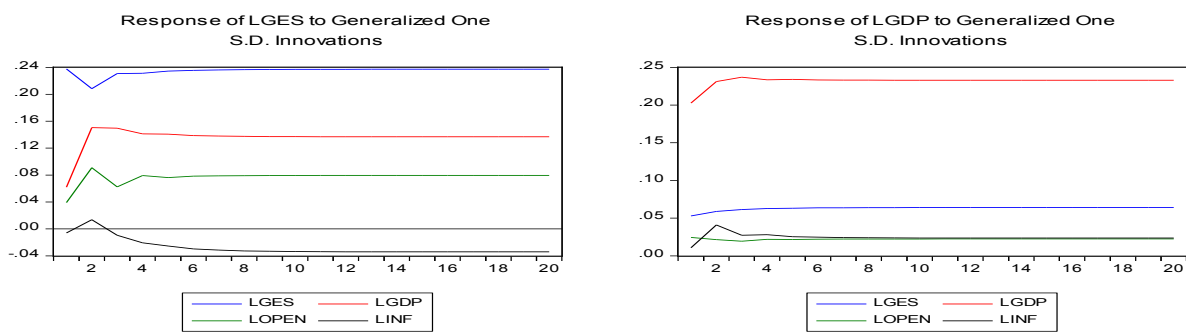

Response of LOPEN to Generalized One S.D. Innovations
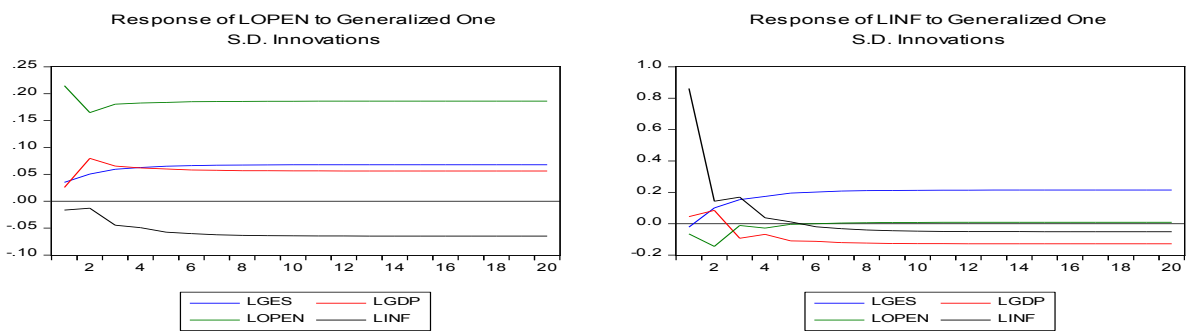

Source: Authors. 
Figure 7.: Impulse Response Functions (IRFs) results - 3o years
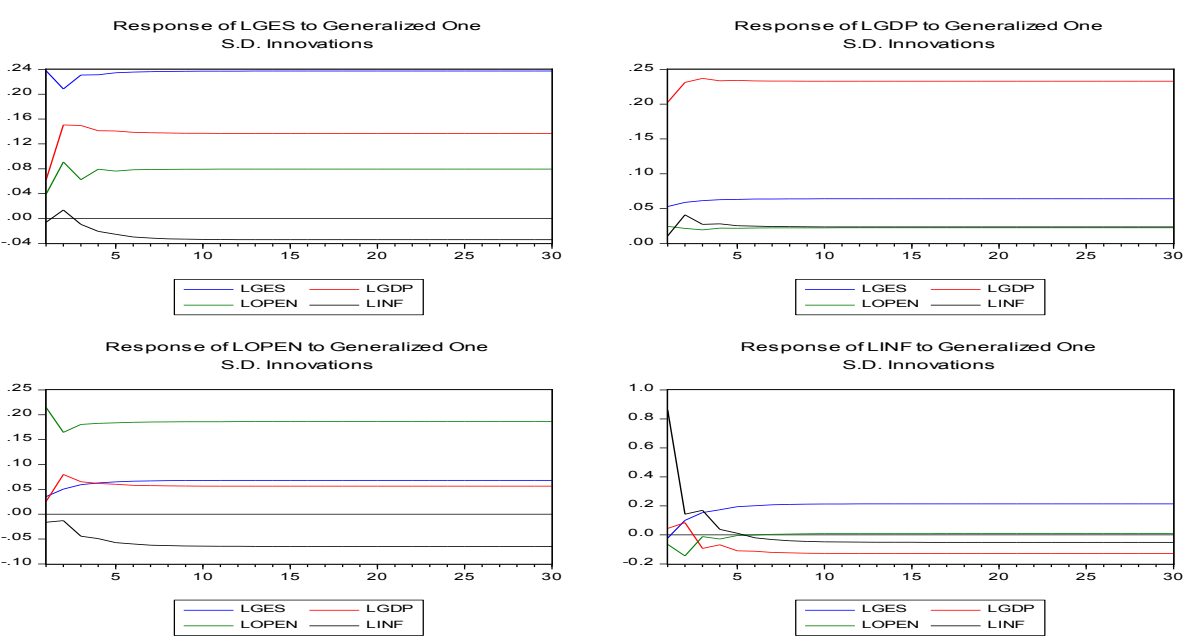

Source: Authors.

\section{CONCLUSION}

The paper examines the government expenditure-national income nexus in Nigeria over the period 1960 - 2012 using nonlinear ARDL and causality approaches. The paper employed the nonlinear ARDL cointegration developed by Shin et al. (2014) and test the causal relationship the variables by employing vector error correction model, variance decompositions and Impulse response functions techniques. The nonlinear ARDL result shows that government expenditure is cointegrated with economic growth. The results provide evidence in support of asymmetric fiscal adjustments, that is, government expenditure reacts differently to increase and decrease in national income in the long run. Specifically, in the long run, decline in national income growth (negative changes) has a larger reducing impact on government expenditure than the increase generated by positive economic growth. The results equally show that government expenditure is associated with both booms (positive growth) and recession (negative growth). The main implication of these findings is that government should ensure that the economy maintains positive growth in order to avoid reduction in government expenditure that is associated with economic downturn. In order to achieve this, government must diversify the economy from oil to agriculture and manufacturing. With the current heavy reliance on oil, the economy is prone to high revenue instability and recession with possible adverse effect on government expenditure.

Finally, the results showed a unidirectional causality running from that national income measured as GDP to government expenditure. Also, the study showed a unidirectional causality from national income to openness and inflation respectively. 
The implication of the causality result is that policymakers should impact national income (GDP) to influence government expenditure. It also suggests that increase in government spending might not necessarily means inefficiency on the part of government as some economists have argued. In addition, effort at rolling back the government through rationalization of government spending might not necessarily have adverse effects on national income. 


\section{REFERENCES}

Adams, A., Sakyi, D., 2012. Globalisation, democracy and government spending in Sub-Saharan Africa: Evidence from panel data. In: Delic, Z., (Ed.), Globalisation and Responsibility, InTech, Croatia, (2012): $137^{-1} 5^{2}$

Ageli, M., Wagner's law of in Saudi Arabia 1970-2012: an econometric analysis. Asian Economic and Financial Review 3(5), (2013): 647-659

Akinlo, A. E., Government spending and economic growth nexus for Nigeria. Global Journal of Business Research $7(1),(2013): 33-41$

Alimi, S., Testing augmented Wagner's law for Nigeria based on cointegration and error-correction modeling techniques. MPRA Paper No. 52319, 2013.

Aregbeyen, O., Cointegration, causality and Wagner's law: a test for Nigeria, 1970-2003. Economic and Financial Review 44(2), (2006): 1-17

Bayrak, M., Esen, O., Examining the validity of Wagner's law in the OECD economies. Research in Applied Economics 6(3), (2014): 1-16

Bird, R., Wagner's law: a pooled time series and cross section comparison. National Tax Journal 38, (1971): 209-218

Dogan, E., Tang, T. C., Government expenditure and national income: causality tests for five South East Asian countries. International Business and Economics Research Journal 5, (2006): 49-58

Ebaidalla, M., Causality between government expenditure and national income: evidence from Sudan. Journal of Economic Cooperation and Development 34.(4), (2013): 61-76

Hercowitz, Z., Stawczynski,M., Cyclical ratcheting in government spending: evidence from the OECD. Review of Economics and Statistics 86(1), (2004): 353-361

Huang, C. J., Government expenditures in China and Taiwan: do they follow Wagner's law? Journal of Economic Development 31(2), (2006): 139-148

Lamartina, S., Zaghini, A., Increasing public expenditure: Wagner's law in OECD countries. German Economic Review 12(2), (2011): 149-164

Mahdavi, S., A re-examination of Wagner's law based on disaggregated U. S. state-local government expenditure. The University Texas at San Antonio, College of Business Working Paper Series WP\#O10ECO-90-2009, 2009.

Okoro, A., Government spending and economic growth in Nigeria (1980-2011). Singaporean Journal of Business Economics and Management Studies 2(5), (2013): 81-92

Olomola, P., Cointegration analysis-causality testing and Wagner's law: the case of Nigeria, 1970-2001. Journal of Social and Economic Development 6(1), (2004): 76-90

Pesaran, B., Pesaran, M. H., Time series econometrics using Microfit 5.0. Oxford University Press, Oxford, 2009.

Pesaran, M. H., Shin, Y., An autoregressive distributed lag modeling approach to cointegration analysis. In Econometrics and economic theory in the 2oth century: The Ragnar Frisch centennial symposium, Edited by S. Strom. Cambridge: Cambridge University Press, 1999.

Pesaran, M. H., Shin, Y., Smith, R. J., Bounds testing approaches to the analysis of level relationships. Journal of Applied Econometrics 16, (2001): 289-326 
Rodrik, D., Why do more open economies have bigger governments? The Journal of Political Economy 106(5), (1998): 997-1032

Shin, Y., Yu, B., Greenwood-Nimmo, M., Modeling asymmetric cointegration and dynamic multiplier in a nonlinear ARDL framework, Mimeo, 2011.

Zivot, E., Andrews D. W. K., Further evidence in the Great Crash, the Oil-Price shock, and the unit root hypothesis. Journal of Business and Economic Statistics 10, (1992): 251-270 
